\title{
Expression optimization of recombinant cholesterol oxidase in Escherichia coli and its purification and characterization
}

\author{
Aliakbar Fazaeli ${ }^{1}$, Abolfazl Golestani ${ }^{1}$, Mostafa Lakzaei ${ }^{1}$, Samaneh Sadat Rasi Varaei ${ }^{1}$ and Mahdi Aminian ${ }^{1,2^{*}}$
}

\begin{abstract}
Cholesterol oxidase is a bacterial flavoenzyme which catalyzes oxidation and isomerization of cholesterol. This enzyme has a great commercial value because of its wide applications in cholesterol analysis of clinical samples, synthesis of steroid-derived drugs, food industries, and potentially insecticidal activity. Accordingly, development of an efficient protocol for overexpression of cholesterol oxidase can be very valuable and beneficial. In this study, expression optimization of cholesterol oxidase from Streptomyces sp. SA-COO was investigated in Escherichia coli host strains. Various parameters that may influence the yield of a recombinant enzyme were evaluated individually. The optimal host strain, culture media, induction time, Isopropyl ß-D-1-thiogalactopyranoside concentration, as well as post-induction incubation time and temperature were determined in a shaking flask mode. Applying the optimized protocol, the production of recombinant cholesterol oxidase was significantly enhanced from 3.2 to $158 \mathrm{U} / \mathrm{L}$. Under the optimized condition, the enzyme was produced on a large-scale, and highly expressed cholesterol oxidase was purified from cell lysate by column nickel affinity chromatography. $K_{m}$ and $V_{\max }$ values of the purified enzyme for cholesterol were estimated using Lineweaver-Burk plot. Further, the optimum $\mathrm{pH}$ and optimum temperature for the enzyme activity were also determined. We report a straightforward and easy protocol for cholesterol oxidase production which can be performed in any laboratory.
\end{abstract}

Keywords: Affinity chromatography, Cholesterol oxidase, Expression optimization, Recombinant enzyme

\section{Introduction}

Cholesterol oxidases (EC 1.1.3.6) are bifunctional bacterial flavoenzymes belonging to the family of oxidoreductase which catalyze the first step in the catabolism of cholesterol. They catalyze oxidation as well as isomerization of cholesterol and produce equimolar amounts of cholest-4-en-3-one coupled with hydrogen peroxide as the final products (Moradpour and Ghasemian 2016). There are two types of cholesterol oxidase $(\mathrm{ChO})$ depending on the nature of the bond between FAD cofactor and apoenzyme. In type I, the FAD cofactor is linked to the protein through a noncovalent bond, while in type II, the cofactor is covalently bond to the apoenzyme (Vrielink

\footnotetext{
*Correspondence: amminian@tums.ac.ir

${ }^{1}$ Department of Clinical Biochemistry, School of Medicine, Tehran

University of Medical Sciences, Tehran, Iran

Full list of author information is available at the end of the article
}

and Ghisla 2009). Both types of enzymes have found wide applications as a useful biotechnological tool.

Cholesterol oxidase is the second most widely used enzyme in clinical laboratories (Doukyu et al. 2009). This enzyme is commonly used for determining cholesterol levels both in serum and in other biological samples (MacLachlan et al. 2000). On the other hand, the ability of cholesterol oxidase in bioconversion of $3 \beta$-hydroxysteroids makes it a valuable enzyme for transformation of sterols and non-sterols in the pharmaceutical industry (Doukyu 2009). Recently, many attempts have been made to reduce cholesterol levels in foods. The reduction of food cholesterol levels may occur via enzymatic methods (Yehia et al. 2015). Many experiments have been conducted to reduce milk and yolk cholesterol levels using cholesterol oxidase (Lv et al. 2002; Serajzadeh and Alemzadeh 2010; Smith et al. 1991). In addition, other investigations have addressed the role of 
cholesterol oxidase as an approach to pest control strategies (Cho et al. 1995; Purcell et al. 1993).

ChO has no mammalian homolog and is totally produced by pathogenic and nonpathogenic bacteria. Pathogenic bacteria employ this enzyme for infection of host macrophages by oxidation of membrane cholesterol, while nonpathogenic bacteria tend to utilize $\mathrm{ChO}$ as a metabolic tool for obtaining carbon sources from cholesterol decomposition (Pollegioni et al. 2009). So far, many efforts have been made to obtain the $\mathrm{ChO}$ from original microorganisms. Nevertheless, this approach suffers from some challenges such as difficult growth conditions and low productivity of original microorganisms (MacLachlan et al. 2000). In order to find a solution for these issues, ChO genes from different bacterial sources have been cloned and expressed which would be effective for commercial application of enzyme production (Brigidi et al. 1993; Corbin et al. 1994; Fujishiro et al. 1990; Horii et al. 1990; Liu et al. 1988; Molnár et al. 1991; Murooka et al. 1986; Nishiya et al. 1997; Ohta et al. 1992; Purcell et al. 1993; Solaiman and Somkuti 1991, 1995; Solaiman et al. 1992; Somkuti et al. 1991, 1995; Somkuti and Solaiman 1997). ChO from Streptomyces sp. SACOO (ChOA) secretory production has been proved in a Streptomyces host-vector system (Murooka et al. 1986). Also, the ChOA gene has been cloned and sequenced (Ishizaki et al. 1989). Nomura et al. successfully expressed the ChOA gene in Escherichia coli (Nomura et al. 1995). Further, the thermal stability of the ChOA was improved in another study (Nishiya et al. 1997).

Recombinant ChOA production in a large quantity facilitates its biochemical characterization and its use in industrial processes. To this end, in the current study, we have taken a straightforward and effective approach to maximize ChOA production by optimizing the culture and induction parameters in shaking flasks.

\section{Materials and methods}

\section{Strains, materials, and culture media}

Escherichia coli host strains BL21(DE3), BL21(DE3)pLysS, and Rosetta-gami2(DE3) were obtained from Novagen (Madison, WI, USA). Synthesis of plasmid pET24b$\mathrm{ChOA}$ was ordered to Bio Basic Inc. (ON, Canada). NiCAM HC Resin, isopropyl- $\beta$-D-thiogalactopyranoside (IPTG), kanamycin and chloramphenicol were purchased from Sigma-Aldrich (MO, USA). All other chemicals were prepared from Merck chemical company (Darmstadt, Germany). The following liquid media were used: Luria-Bertani (LB, $10 \mathrm{~g} / \mathrm{L}$ peptone, $5 \mathrm{~g} / \mathrm{L}$ yeast extract, $5 \mathrm{~g} / \mathrm{L} \mathrm{NaCl}$, Merck), Super Broth (SB, $32 \mathrm{~g} / \mathrm{L}$ peptone, $20 \mathrm{~g} / \mathrm{L}$ yeast extract and $5 \mathrm{~g} / \mathrm{L} \mathrm{NaCl}$, Merck), Terrific Broth (TB, $12 \mathrm{~g} / \mathrm{L}$ peptone, $24 \mathrm{~g} / \mathrm{L}$ yeast extract, $8 \mathrm{~g} / \mathrm{L}$ glycerol, $17 \mathrm{mM} \mathrm{KH}_{2} \mathrm{PO}_{4}$ and $72 \mathrm{mM} \mathrm{K}_{2} \mathrm{HPO}_{4}$, Merck).

\section{Optimization of recombinant ChOA expression \\ Expression of ChOA in different $E$. coli hosts}

Initially, three different $E$. coli strains capability for the production of recombinant ChOA were assessed under our routine laboratory conditions. At first, ChoA gene (GenBank accession number M31939) was designed into pET24b $(+)$ expression plasmid between NdeIBamHI restriction sites (GenBank accession number MH810339). Then, $1 \mu \mathrm{L}$ of pET24-ChOA plasmid was transformed into chemically competent cells of BL21(DE3), BL21(DE3)pLysS, and Rosetta-gami2(DE3) host strains. We used $50 \mu \mathrm{g} / \mathrm{mL}$ kanamycin in the solid and liquid medium of each of the three strains and additional $25 \mu \mathrm{g} / \mathrm{mL}$ chloramphenicol in the case of BL21(DE3)pLysS and Rosetta-gami2(DE3). After overnight incubation, a single colony of each strain was taken from $\mathrm{LB}$ agar plates and used for inoculation of $3 \mathrm{~mL}$ preculture media and incubated at $37^{\circ} \mathrm{C}, 160 \mathrm{rpm}$ for $12 \mathrm{~h}$. On the following day, $10 \mathrm{~mL}$ of LB media was inoculated by $100 \mu \mathrm{L}$ of pre-culture media and incubated under the same conditions. When the optical density at $600 \mathrm{~nm}$ $\left(\mathrm{OD}_{600 \mathrm{~nm}}\right)$ reached 0.6, IPTG was added up to a final concentration of $0.5 \mathrm{mM}$. The cells were harvested after $6 \mathrm{~h}$ by centrifugation at $7000 \times g, 4{ }^{\circ} \mathrm{C}$, and within $10 \mathrm{~min}$. The harvested cells were resuspended in $0.5 \mathrm{~mL}$ of PBS buffer containing $\mathrm{NaCl}(0.3 \mathrm{M})$ at $\mathrm{pH}$ 7. Bacterial cells were disrupted by sonication and the lysate was centrifuged at $13,000 \times g, 4{ }^{\circ} \mathrm{C}$, within $20 \mathrm{~min}$. The productivity of each host strain was evaluated by enzyme activity assay in the crude extract. ChOA activity was measured at $25{ }^{\circ} \mathrm{C}$ by a modification of the method of Allain et al. (1974) and Doukyu et al. (2008). The assay mixture contained $100 \mathrm{mM}$ potassium phosphate $\mathrm{pH}$ 7.0, $1 \mathrm{mM}$ cholesterol, $21 \mathrm{mM}$ phenol, $1.4 \mathrm{mM}$ 4-aminoantipyrine and $5 \mathrm{U} /$ $\mathrm{mL}$ peroxidase. The reaction was started by addition of $100 \mu \mathrm{L}$ sample to $1 \mathrm{~mL}$ assay mixture and the appearance of the red chromophore was monitored continuously at $500 \mathrm{~nm}$. Blanks without enzyme or without cholesterol were routinely run in parallel. One unit of activity was defined as the formation of $1 \mu \mathrm{mol}$ of hydrogen peroxide $\left(0.5 \mu \mathrm{mol}\right.$ of quinoneimine dye) per min at $25^{\circ} \mathrm{C}$.

\section{Culture media optimization}

To determine the optimal culture media, the overnight culture of $B L 21(D E 3) p L y s S$ harboring pET24-ChOA plasmid was made in $3 \mathrm{~mL}$ of LB media. Then, $10 \mathrm{~mL}$ of three different medium types including $\mathrm{LB}, \mathrm{TB}$, and $\mathrm{SB}$ were inoculated with a pre-culture with the ratio of 1:100. When $\mathrm{OD}_{600 \mathrm{~nm}}$ reached 0.6 , the cultures were induced with $0.5 \mathrm{mM}$ IPTG and incubated at $37{ }^{\circ} \mathrm{C}, 160 \mathrm{rpm}$ for $6 \mathrm{~h}$. The cultures were harvested and the pellet was resuspended in $0.5 \mathrm{~mL}$ of PBS buffer. After sonication, the 
cell lysate was centrifuged at $13,000 \times g, 4{ }^{\circ} \mathrm{C}$, for $20 \mathrm{~min}$. The total activity of recombinant ChOA was measured by performing enzyme assay in the supernatant crude extract to determine productivity.

\section{Optimum induction time}

BL21(DE3)pLysS cells containing pET24-ChOA were grown overnight in LB media. Fresh culture (4 flasks) containing $10 \mathrm{~mL}$ TB media was inoculated (1:100) and incubated at $37{ }^{\circ} \mathrm{C}, 160 \mathrm{rpm}$. When the $\mathrm{OD}_{600 \mathrm{~nm}}$ of cultures reached 0.3, 0.6, 1.2 and 1.8, induction was made with $0.5 \mathrm{mM}$ IPTG. Each culture was incubated for $6 \mathrm{~h}$ at $37{ }^{\circ} \mathrm{C}, 160 \mathrm{rpm}$. The harvested cells were resuspended in $0.5 \mathrm{~mL}$ of buffer (PBS, pH 7) and disrupted by sonication, then centrifuged at $13,000 \times g, 4{ }^{\circ} \mathrm{C}$, for $20 \mathrm{~min}$. Quantification of active (soluble) enzyme was performed by enzyme activity assay.

\section{Optimum IPTG concentration}

The effects of various IPTG concentrations on ChOA productivity were further evaluated. For this purpose, five flasks containing $10 \mathrm{~mL}$ of TB media were inoculated by a pre-culture with the ratio of 1:100. The cultures were incubated at $37^{\circ} \mathrm{C}, 160 \mathrm{rpm}$ until $\mathrm{OD}_{600 \mathrm{~nm}}$ reached 0.6 . The cell cultures were induced by IPTG concentrations of $0.05,0.1,0.25,0.5$, and $1 \mathrm{mM}$ respectively. After disruption and centrifugation of harvested cells, enzyme expression was measured by enzyme activity assay.

\section{Induction temperature and post-induction incubation time}

The productivity of recombinant ChOA was evaluated at different incubation temperatures $\left(15^{\circ} \mathrm{C}, 25^{\circ} \mathrm{C}\right.$, and $37{ }^{\circ} \mathrm{C}$ ), as well as four different post-induction incubation times $(6,8,16$, and $24 \mathrm{~h})$. These parameters were investigated in three flasks containing $20 \mathrm{~mL}$ of $\mathrm{TB}$ media, inoculated by $0.2 \mathrm{~mL}$ of pre-cultured BL21(DE3) pLysS harboring $C h O A$ gene. The induction was done at $\mathrm{OD}_{600 \mathrm{~nm}} \simeq 0.6$ by adding IPTG in a final concentration of $0.25 \mathrm{mM}$. After the induction, the flasks were incubated at $15{ }^{\circ} \mathrm{C}, 25^{\circ} \mathrm{C}$, and $37{ }^{\circ} \mathrm{C}$ on a rotary shaker with a speed of $160 \mathrm{rpm}$. In order to determine the optimal post-induction incubation time, $2 \mathrm{~mL}$ of culture media from each flask was withdrawn at different time $(6,8$, 16 , and $24 \mathrm{~h}$ ) intervals. The collected samples were centrifuged and pellets were resuspended in the buffer, and then the cells were disrupted by sonication. Once the samples were prepared, enzyme activity assay performed for quantification of the expressed recombinant enzyme.

Large-scale expression of ChOA under optimized condition Overexpression of $\mathrm{ChOA}$ gene was performed according to the results of optimized protocol. A pre-culture was made by inoculating $5 \mathrm{~mL}$ of LB media containing kanamycin $(50 \mu \mathrm{g} / \mathrm{mL})$ and chloramphenicol $(25 \mu \mathrm{g} /$ $\mathrm{mL}$ ) with pET24-ChOA harboring BL21(DE3)pLysS cells. Then, $500 \mathrm{~mL}$ of TB media containing $50 \mu \mathrm{g} / \mathrm{mL}$ kanamycin and $25 \mu \mathrm{g} / \mathrm{mL}$ chloramphenicol was inoculated by the pre-culture. When $\mathrm{OD}_{600 \mathrm{~nm}}$ reached 0.6 , induction of $C h O A$ gene expression was done by adding IPTG up to a final concentration of $0.25 \mathrm{mM}$ and continued with $24 \mathrm{~h}$ incubation at $15{ }^{\circ} \mathrm{C}, 160 \mathrm{rpm}$. The harvested bacterial pellet was resuspended in $10 \mathrm{~mL}$ of buffer (PBS, $\mathrm{NaCl}$ $0.3 \mathrm{M}$, and Imidazole $5 \mathrm{mM}, \mathrm{pH}$ 7) and disrupted by sonication. The cell lysate was centrifuged at $13,000 \times g, 4{ }^{\circ} \mathrm{C}$, for $20 \mathrm{~min}$ and the supernatant used for ChOA purification via affinity chromatography.

\section{Purification of recombinant ChOA}

Recombinant ChOA containing $\mathrm{N}$-terminal His tag was purified from the soluble crude extract using nickel affinity chromatography (Ni-CAM HC Resin). The column $(2 \mathrm{~mL})$ was equilibrated with $30 \mathrm{~mL}$ of equilibration buffer (PBS, Imidazole $5 \mathrm{mM}, \mathrm{NaCl} 0.3 \mathrm{M}$; pH 7) at $1 \mathrm{~mL} / \mathrm{min}$. The supernatant was loaded onto the column and the column was washed with equilibrium buffer until the absorbance at $280 \mathrm{~nm}$ reached the basal level. To elute the protein, elution buffer (PBS, $\mathrm{NaCl} 0.3 \mathrm{M}$, and Imidazole $200 \mathrm{mM}$; pH 7) was used, and the released proteins were fractionated. The purity of the fractionated samples was evaluated by SDS-PAGE $12 \%$. The pure fractions were pooled together and dialyzed against $50 \mathrm{mM}$ sodium phosphate buffer at $4{ }^{\circ} \mathrm{C}, \mathrm{pH} 7$ for $16 \mathrm{~h}$. Enzyme activity and protein concentration of the crude extract, flow-through, and pure enzyme were determined using the enzyme activity assay and Bradford protein assay (Aminian et al. 2013) and the resulting data used for determining purification yield and specific activity of recombinant ChOA.

\section{Kinetic characterization of purified $\mathrm{ChOA}$}

The optimum $\mathrm{pH}$ for the recombinant enzyme activity was determined by the enzyme activity assay at $30{ }^{\circ} \mathrm{C}$ under various $\mathrm{pH}(3-11)$ conditions. The buffer systems were prepared according to Doukyu et al. (Doukyu et al. 2008). The recombinant ChOA activity was also assayed at different temperatures $\left(30{ }^{\circ} \mathrm{C}-80{ }^{\circ} \mathrm{C}\right)$ in order to determine the recombinant enzyme optimum thermal activity. The $\mathrm{K}_{\mathrm{m}}$ and $\mathrm{V}_{\max }$ values for cholesterol were estimated from Lineweaver-Burk plots of data obtained with the assay solution containing $0-1 \mathrm{mM}$ cholesterol.

\section{Results}

Optimization of recombinant ChOA expression Optimal host strain for ChOA expression

Evaluation of the E. coli host strains productivity for producing recombinant ChOA was performed 


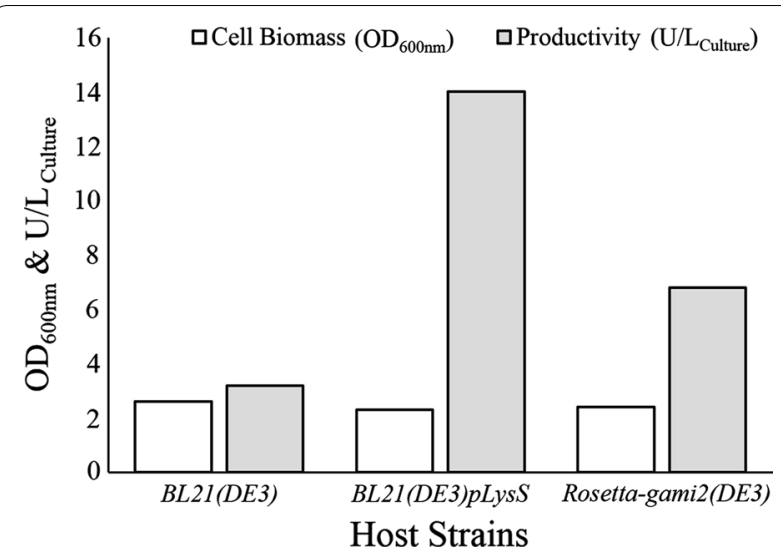

Fig. 1 Influence of various hosts on the total productivity of recombinant ChOA and cell biomass production after $6 \mathrm{~h}$ post-induction incubation at $37^{\circ} \mathrm{C}$

by transformation of pET24-ChOA plasmid into BL21(DE3), BL21(DE3)pLysS, and Rosetta-gami2(DE3). The host strains were simultaneously induced with $0.5 \mathrm{mM}$ IPTG and the protein expression continued for $6 \mathrm{~h}$ at $37^{\circ} \mathrm{C}, 160 \mathrm{rpm}$. Following sonication, the cell lysates were centrifuged to remove insoluble materials, and the resulting supernatants were collected to determine the units of enzyme produced per liter of the culture media. The BL21(DE3)pLysS cells yielded the maximum level of active recombinant ChOA with $14 \mathrm{U} / \mathrm{L}$ activity (Fig. 1). In addition, the total amount of active enzyme obtained from Rosetta-gami2(DE3) $(6.8 \mathrm{U} / \mathrm{L})$ was higher than that of BL21(DE3) $(3.2 \mathrm{U} / \mathrm{L})$.

\section{Optimal culture media for ChOA expression}

To achieve the optimum production of soluble ChOA in BL21(DE3)pLysS, three different culture media (LB, TB, and $\mathrm{SB}$ ) were evaluated. To compare the effect of the different culture media, overnight culture of BL21(DE3) pLysS containing pET24-ChOA was developed in LB at $37{ }^{\circ} \mathrm{C}$. Pre-culture inoculum (1\%) was transformed into freshly prepared LB, TB, and SB media and incubated at $37{ }^{\circ} \mathrm{C}$ until $\mathrm{OD}_{600 \mathrm{~nm}}$ reached 0.6. Subsequently, the cultures were induced with $0.5 \mathrm{mM}$ IPTG and were grown for another $6 \mathrm{~h}$ at $37{ }^{\circ} \mathrm{C}, 160 \mathrm{rpm}$. Comparison of cell density and total enzyme activity in different media is demonstrated in Fig. 2. The highest biomass accumulation $\left(\mathrm{OD}_{600 \mathrm{~nm}}=3.9\right)$ was achieved by TB medium. Also, ChOA assay indicated that recombinant protein productivity increased in TB medium when compared to the other media.

\section{Pre-induction growth optimization}

In order to determine the optimum induction time, four shake flasks were examined in parallel, with each

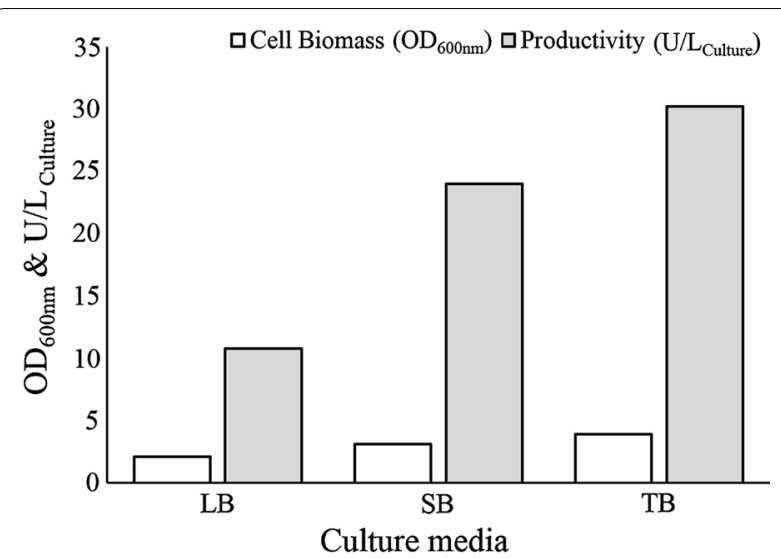

Fig. 2 ChOA productivity and cell biomass accumulation in various culture media

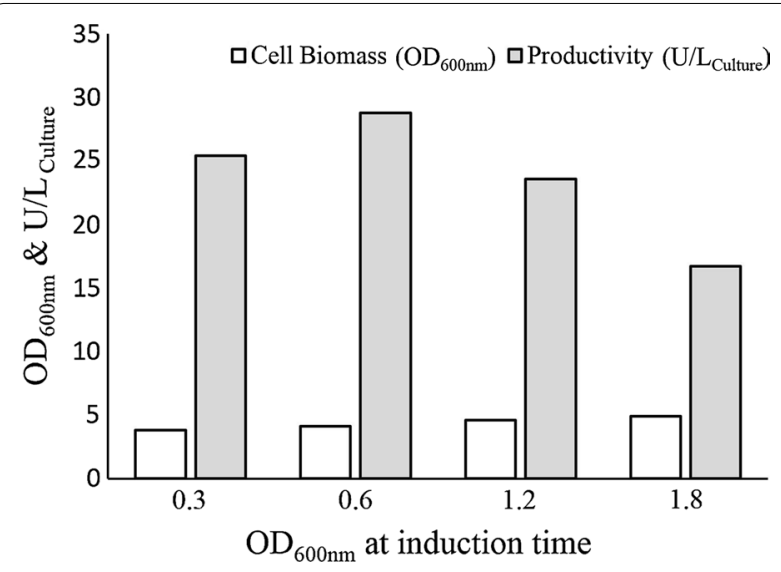

Fig. 3 Effect of pre-induction growth on the final growth rate and ChOA expression. Protein expression was induced at various bacterial growth phases $(0.3,0.6,1.2$, and 1.8$)$

culture induced at different growth phases. Cultures were induced with $0.5 \mathrm{mM}$ IPTG when the $\mathrm{OD}_{600 \mathrm{~nm}}$ reached $0.3,0.6,1.2$, and 1.8 , representing early exponential, midexponential, late exponential, and stationary phases, respectively. The results, depicted in Fig. 3, indicate that ChOA yield was maximized to $28.8 \mathrm{U} / \mathrm{L}$ when induction was made at the mid-exponential growth phase $\left(\mathrm{OD}_{600 \mathrm{~nm}}=0.6\right)$.

\section{Inducer concentration optimization}

Further, the effect of IPTG concentrations $(0.05,0.1,0.25$, $0.5,1 \mathrm{mM})$ on ChOA productivity was investigated under the best conditions achieved so far (BL21(DE3)pLysS, TB medium, induction at $\left.\mathrm{OD}_{600 \mathrm{~nm}}=0.6\right)$. Figure 4 presents the results obtained by the performed experiments. As IPTG gradually increased up to $0.25 \mathrm{mM}$, the productivity also increased in the same way. Nevertheless, beyond $0.25 \mathrm{mM}$, reduction in the active enzyme yield was observed. 


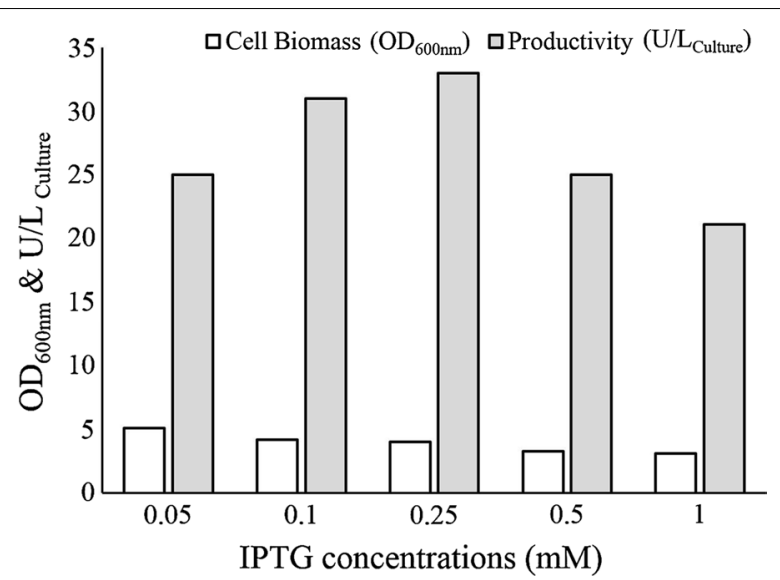

Fig. 4 ChOA activity levels and cell growth at various IPTG concentrations $(0.05,0.1,0.25,0.5$, and $1 \mathrm{mM})$ after $6 \mathrm{~h}$ incubation at $37^{\circ} \mathrm{C}$

\section{Optimal induction temperature and post-induction incubation time}

To determine the optimal induction temperature and post-induction incubation time, three flasks containing TB media were cultivated under previously optimized conditions. After addition of IPTG $(0.25 \mathrm{mM})$, the flasks were incubated at $15{ }^{\circ} \mathrm{C}, 25{ }^{\circ} \mathrm{C}$, and $37{ }^{\circ} \mathrm{C}$, separately. During incubation, $2 \mathrm{~mL}$ of culture was withdrawn from each flask at different time intervals $(6,8,16$, and $24 \mathrm{~h})$. Enzyme activity assay revealed that recombinant ChOA production was markedly increased considerably when the induced culture medium was incubated at $15{ }^{\circ} \mathrm{C}$ for $24 \mathrm{~h}$. As summarized in Fig. 5, the cell density and total enzyme activity decreased when the cultures were incubated at $37^{\circ} \mathrm{C}$ even for 16 or $24 \mathrm{~h}$.

\section{Large-scale enzyme production}

All the results above were obtained from small-scale cultures. Collecting all the optimal conditions together, we performed $500 \mathrm{~mL}$ culture of BL21(DE3)pLysS-pET24$\mathrm{ChOA}$ at $15{ }^{\circ} \mathrm{C}$ for $24 \mathrm{~h}$ by induction with $0.25 \mathrm{mM}$ IPTG at the mid-exponential phase $\left(\mathrm{OD}_{600 \mathrm{~nm}} \simeq 0.6\right)$. After sonication and obtaining a clarified crude extract by centrifugation, the total enzyme activity and total protein concentration were measured. As shown in Table 1, the total enzyme activity and total protein content were $78.5 \mathrm{U}$ and $63 \mathrm{mg}$, respectively.

\section{Purification of recombinant $\mathrm{ChOA}$}

The recombinant ChOA protein containing $\mathrm{N}$-terminal $6 \times$ His-Tag was purified by nickel column affinity chromatography. The pre-column, flow-through, and eluted fractions were analyzed by SDS-PAGE, with the results indicating that pure ChOA was efficiently eluted by $200 \mathrm{mM}$ imidazole. As displayed in Fig. 6, lanes 5-9, ChOA was highly purified. Eluted fractions containing pure ChOA were pooled and dialyzed against $50 \mathrm{mM}$ of sodium phosphate buffer at $\mathrm{pH} 7$. Table 1 summarizes the data of purification steps. The overall yield of $86 \%$ and the approximately 5.7 -fold increase in the overall purification were achieved by $\mathrm{Ni}$-CAM affinity chromatography.

\section{Properties of the purified cholesterol oxidase}

The ChOA activity was measured at different values of $\mathrm{pH}$ and temperature. The enzyme activity retained more than $95 \%$ of its maximal activity within the $\mathrm{pH}$ range of $6-7$ at $25^{\circ} \mathrm{C}$ (Fig. 7a). The optimum temperature for the ChOA activity was determined, with the results indicating that the optimal temperature for ChOA activity was $60{ }^{\circ} \mathrm{C}$ (Fig. 7b). Further, the enzyme retained more than

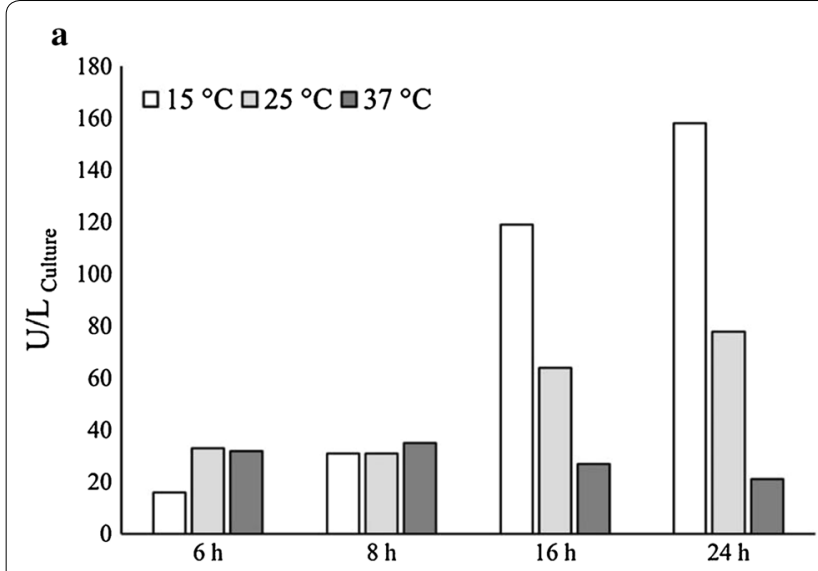

Post-induction incubation time

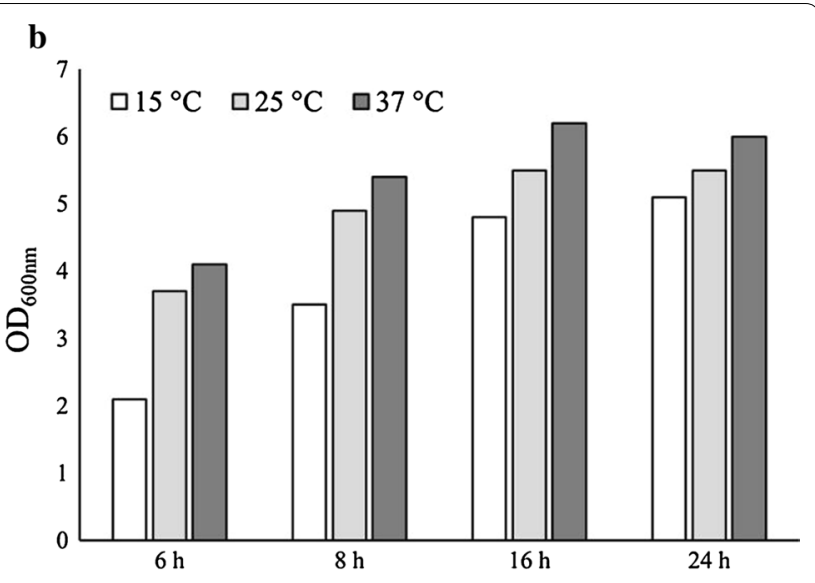

Post-induction incubation time

Fig. 5 Comparison of ChOA production (a) and the cell growth (b) at various temperature and post-induction incubation times 
Table 1 Summary of the purification procedure for the recombinant choA

\begin{tabular}{llllll}
\hline Steps & $\begin{array}{l}\text { Total } \\
\text { activity }^{\mathbf{a}}\end{array}$ & $\begin{array}{l}\text { Total } \\
\text { (U) }\end{array}$ & $\begin{array}{l}\text { Specific } \\
\text { (mg) }\end{array}$ & $\begin{array}{l}\text { Purification } \\
\text { activity } \\
\text { (U/mg) }\end{array}$ & $\begin{array}{l}\text { Yield (\%) } \\
\text { (fold) }\end{array}$ \\
\hline $\begin{array}{l}\text { Crude } \\
\text { extract }\end{array}$ & 78.5 & 63 & 1.25 & 1 & 100 \\
$\begin{array}{c}\text { Ni-CAM } \\
\text { affinity } \\
\text { chroma- } \\
\text { tography }\end{array}$ & 67.7 & 9.57 & 7.07 & 5.66 & 86.2 \\
\hline
\end{tabular}

a Cholesterol oxidation activity was assayed by measuring $\mathrm{H}_{2} \mathrm{O}_{2}$ generation

b Crude extract was obtained from $500 \mathrm{~mL}$ of the culture of BL21(DE3)pLysSpET24-ChoA

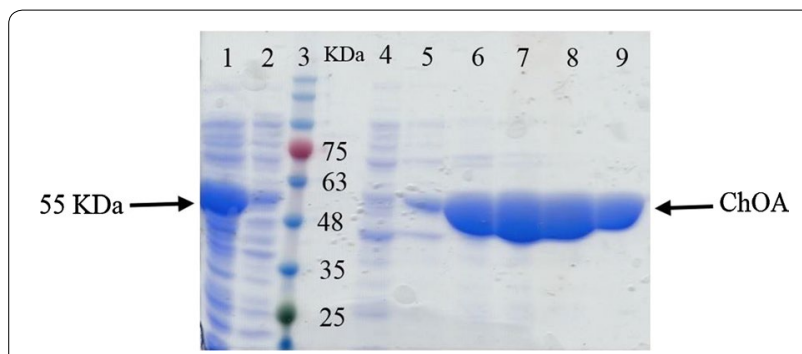

Fig. 6 SDS-PAGE analysis of recombinant ChOA purification steps. Lane 1: crude extract, lane 2: column flow-through, lane 3: protein marker, lane 4: 50 mM imidazole elution, lanes 5-9: 200 mM imidazole elution

$60 \%$ of its activity at the temperatures from $40{ }^{\circ} \mathrm{C}$ to $70{ }^{\circ} \mathrm{C}$ under the test conditions. In addition, the enzyme had a relatively low activity at $30{ }^{\circ} \mathrm{C}(42 \%)$ and $80{ }^{\circ} \mathrm{C}(24 \%)$ compared to $60^{\circ} \mathrm{C}$. To calculate the $\mathrm{K}_{\mathrm{m}}$ and $\mathrm{V}_{\max }$ values of purified ChOA, the activity of the enzyme was assayed with a range of cholesterol concentrations $(0-1 \mathrm{mM})$ at

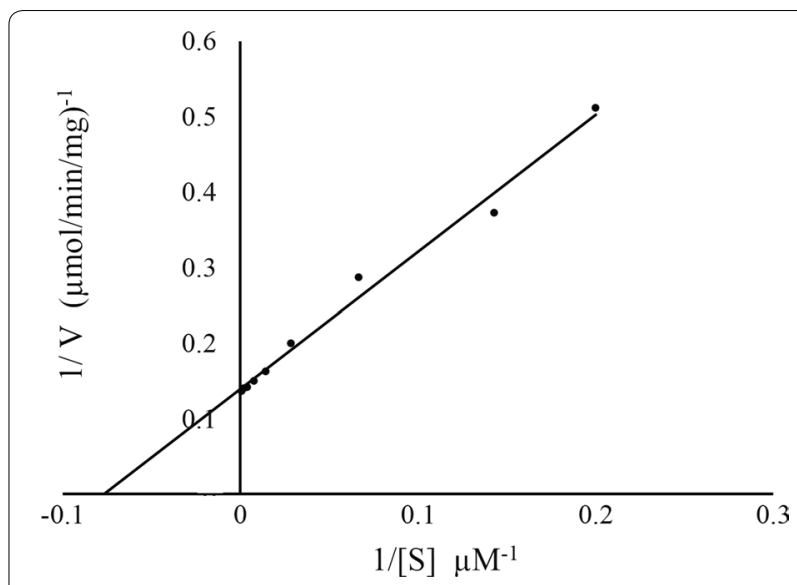

Fig. 8 Lineweaver-Burk plot for cholesterol oxidase in the presence of various concentrations of cholesterol $(0-1 \mathrm{mM})$ as substrate

$25^{\circ} \mathrm{C}, 0.1 \mathrm{M}$ of potassium phosphate buffer $\mathrm{pH}$ 7. For $\mathrm{K}_{\mathrm{m}}$ and $\mathrm{V}_{\max }$ estimation, $1 / \mathrm{V}$ was plotted against $1 /[\mathrm{S}]$ in a Lineweaver-Burk plot (Fig. 8). Results indicated that the $K_{m}$ and $V_{\max }$ values were found to be $13 \mu \mathrm{M}$ and $7.2 \mu \mathrm{mol} \mathrm{min}^{-1} \mathrm{mg}^{-1}$ respectively.

\section{Discussion}

Cholesterol oxidase as a bacterial flavoenzyme has a great commercial value with a wide range of applications in various fields (Kumari and Kanwar 2012). In light of this, the most efficient production of the enzyme is desired in a recombinant form. There are several obstacles against the heterologous protein expression which results in the production of a recombinant protein at a very low or zero level. One of the simplest ways to address these issues is selecting a suitable host strain and optimizing the expression conditions (Rosano and Ceccarelli 2014). In the
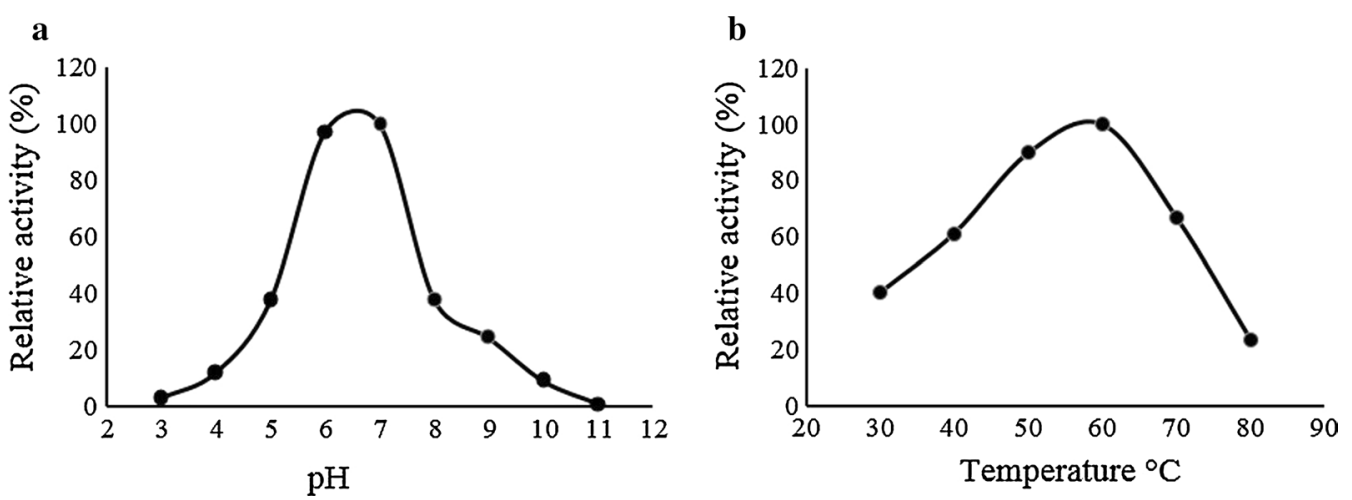

Fig. 7 Effect of different $\mathrm{pH}$ and temperatures on the activity of the recombinant ChOA. a Effect of $\mathrm{pH}$ : The residual activity was examined by monitoring $\mathrm{H}_{2} \mathrm{O}_{2}$ generation at $25^{\circ} \mathrm{C}$. The buffer systems $(0.1 \mathrm{M})$ utilized were glycine- $\mathrm{HCl}\left(\mathrm{pH}\right.$ 3.0), citrate-sodium citrate $(\mathrm{pH} 4.0), \mathrm{CH}{ }_{3} \mathrm{COOH}-$ $\mathrm{CH}_{3} \mathrm{COONa}$ (pH 5.0), $\mathrm{NaH}_{2} \mathrm{PO}_{4}-\mathrm{Na}_{2} \mathrm{HPO}_{4}\left(\mathrm{pH}\right.$ 6.0), Tris- $\mathrm{HCl}$ (pH 7.0-9.0), and $\mathrm{Na}_{2} \mathrm{CO}_{3}-\mathrm{NaHCO}_{3}$ (pH 10.0-11.0). b Effect of temperature: enzyme activity was assayed in $0.1 \mathrm{mM}$ potassium phosphate buffer $\mathrm{pH} 7.0$ at the indicated temperatures 
current study, several parameters were selected for optimization of the cholesterol oxidase production.

In the first step, three different $E$. coli hosts were used to produce recombinant ChOA. Among them, $B L 21(D E 3) p L y s S$ expressed relatively high levels of the active enzyme. pET expression system based on T7 promoter was used for efficient expression of our desired gene. High transcription rate is the advantage of this system but in some cases, this can lead to accumulation of misfolded proteins in inclusion body due to saturation of protein folding machinery (Bahreini et al. 2014). $B L 21(D E 3) p L y s S$ was designed to resolve this problem. In this way, pLyS plasmid consistently produces phage T7 lysozyme which can bind to T7 RNA polymerase and partially prevents the transcription of the recombinant gene that is under the control of T7 promoter (Stano and Patel 2004).

Culture media should be accurately selected given their effect on cell growth and metabolism. Therefore, the yield of protein expression may be affected by culture media composition (Sivashanmugam et al. 2009). In this regard, we performed our experiments using three different media consisting of $\mathrm{LB}, \mathrm{SB}$, and TB. We found that cholesterol oxidase productivity in TB media increased approximately by three times in comparison with LB media. High concentrations of yeast extract, superior buffering capacity, and the use of glycerol as the carbon source supplement enable high biomass accumulation and high ChOA production (Collins et al. 2013).

Bacterial growth phase at the time of induction as well as inducer concentration also affect the production of recombinant proteins (Ahmad et al. 2018). Accordingly, the effects of these parameters on our target protein yield were next examined individually. Figure 3 indicates that the productivity of the enzyme did not change significantly when IPTG was added during the entire exponential phase. However, the expression level decreased when induction was made at the stationary growth phase. Evaluation of biomass production during different induction times revealed that the addition of IPTG at the early exponential phase reduced biomass production; in return IPTG addition at the stationary phase led to increased biomass accumulation. When induction was made at the early exponential growth phase, the bacterial metabolic resources were channeled to producing recombinant protein constituting $50 \%$ of the total cellular protein (Jevševar et al. 2005; Jin et al. 2012). Based on this reasoning, we should expect lowered cellular growth rate following the early exponential phase induction. Our experiment also showed that great production of recombinant ChOA was obtained when IPTG concentration was $0.25 \mathrm{mM}$.
Several studies have suggested that post-induction temperature as well as incubation time can affect the activity and yield of recombinant protein production (Caspeta et al. 2009; Khow and Suntrarachun 2012; Sahdev et al. 2008; Saïda 2007). In addition, Mizukami et al. have reported that different expression temperatures finally led to equal-mass production of the recombinant enzyme with different total activity. They suggested that in the cells cultured at a lower temperature the recombinant enzyme seems to exist as an active form, while as a rather denatured form in the cells cultured at a higher temperature (Mizukami et al. 1986). In light of these findings, we also investigated the effect of different postinduction temperatures $\left(15{ }^{\circ} \mathrm{C}, 25^{\circ} \mathrm{C}\right.$, and $\left.37{ }^{\circ} \mathrm{C}\right)$ along with post-induction incubation times $(6,8,16$, and 24$)$ on the yield of recombinant ChOA. As can be seen clearly in Fig. 5, reducing temperature down to $15^{\circ} \mathrm{C}$ together with extending the incubation period up to $24 \mathrm{~h}$ enhanced the enzyme productivity by approximately 7.5 times relative to the same condition at $37^{\circ} \mathrm{C}$. Generally, metabolic burden usually occurs in recombinant bacteria (Bentley et al. 1990). Accordingly, high-rate produced recombinant proteins may accumulate in insoluble aggregates (inclusion body) as a direct consequence of overwhelming the host folding machinery (Sørensen and Mortensen 2005). In addition, hydrophobic interactions which are a key factor in the formation of inclusion bodies would decline if temperature is lowered (Kiefhaber et al. 1991; Löw et al. 2012; Ma et al. 2013).

Furthermore, in order to study the enzymatic characteristics of the recombinant ChOA, large-scale production of ChOA was performed under the optimized conditions. Maximum yield of recombinant ChOA production was determined to be $1.25 \mathrm{U} / \mathrm{mg}$. Nomura et al. produced ChOA by Streptomyces sp. SA-COO and E. coli JM109. They achieved $0.69 \mathrm{U} / \mathrm{mg}$ ChOA when cholesterol oxidase was produced by Streptomyces sp. SA-COO. Further, they obtained $1.5 \mathrm{U} / \mathrm{mg}$ recombinant enzyme when $\mathrm{N}$-terminal modified $\mathrm{ChOA}$ was expressed in $E$. coli JM109. The characterization of purified recombinant ChOA indicated that the recombinant enzyme was most active at $50{ }^{\circ} \mathrm{C}-70{ }^{\circ} \mathrm{C}$, with $60{ }^{\circ} \mathrm{C}$ being the optimum temperature, which is the same as that of other Streptomycetes (Lartillot and Kedziora 1990; Nishiya et al. 1997; Tabatabaei Yazdi et al. 2001; Tomioka et al. 1976). However, the enzyme retained only $24 \%$ of its activity at $80{ }^{\circ} \mathrm{C}$. Furthermore, activity assay at different $\mathrm{pH}$ values revealed that the optimum $\mathrm{pH}$ for enzyme activity was 7. Most reports have demonstrated the optimum $\mathrm{pH}$ for cholesterol oxidase from other Streptomycetes as about 6.5-8 (Kamei et al. 1978; Lartillot and Kedztora 1990; Smith and Brooks 1976). The $K_{m}$ value for cholesterol was calculated to be $13 \mu \mathrm{M}$ for purified ChOA. This value 
is consistent with the study of Nishiya et al. (Nishiya et al. 1997), which is lower than that of the enzymes from $S$. hygroscopicus and S. virginiae (Gadda et al. 1997; Li et al. 2010).

In conclusion, the results of our study suggested that optimization of ChOA expression conditions in $E$. coli significantly enhanced the enzyme productivity by approximately 50 times. The affinity purified ChOA retained the enzyme characteristics as reported previously.

\section{Authors' contributions \\ AF performed experiments and wrote the manuscript. AG designed experi- ments. ML and SV helped with the experimentation. MA designed and directed experiments, analyzed data and revised the manuscript. All authors read and approved the final manuscript.}

\section{Author details}

${ }^{1}$ Department of Clinical Biochemistry, School of Medicine, Tehran University of Medical Sciences, Tehran, Iran. ${ }^{2}$ Recombinant Vaccine Research Center, Tehran University of Medical Sciences, Tehran, Iran.

\section{Competing interests}

The authors declare that they have no competing interests.

\section{Availability of data and materials}

All data generated or analyzed during this study are included in this published article.

\section{Consent for publication}

Provided during submission process. Not applicable.

\section{Compliance with ethical standards}

This study was reviewed and approved by the Ethics Committee of the Tehran University of Medical Sciences (IR.TUMS.REC.1395.2376).

\section{Funding}

This study was funded by Tehran University of Medical Sciences (Grant Number 30859).

\section{Publisher's Note}

Springer Nature remains neutral with regard to jurisdictional claims in published maps and institutional affiliations.

Received: 7 August 2018 Accepted: 29 October 2018

Published online: 12 November 2018

\section{References}

Ahmad I, Nawaz N, Darwesh NM, Ur Rahman S, Mustafa MZ, Khan SB, Patching SG (2018) Overcoming challenges for amplified expression of recombinant proteins using Escherichia coli. Protein Expr Purif 144:12-18. https:// doi.org/10.1016/j.pep.2017.11.005

Allain CC, Poon LS, Chan CS, Richmond W, Fu PC (1974) Enzymatic determination of total serum cholesterol. Clin Chem 20(4):470-475

Aminian M, Nabatchian F, Vaisi-Raygani A, Torabi M (2013) Mechanism of Coomassie Brilliant Blue G-250 binding to cetyltrimethylammonium bromide: an interference with the Bradford assay. Anal Biochem 434(2):287-291

Bahreini E, Aghaiypour K, Abbasalipourkabir R, Goodarzi MT, Saidijam M, Safavieh SS (2014) An optimized protocol for overproduction of recombinant protein expression in Escherichia coli. Prep Biochem Biotechnol 44(5):510-528. https://doi.org/10.1080/10826068.2013.833116

Bentley WE, Mirjalili N, Andersen DC, Davis RH, Kompala DS (1990) Plasmidencoded protein: the principal factor in the "metabolic burden" associated with recombinant bacteria. Biotechnol Bioeng 35(7):668-681. https://doi.org/10.1002/bit.260350704

Brigidi P, Bolognani F, Rossi M, Cerre C, Matteuzzi D (1993) Cloning of the gene for cholesterol oxidase in Bacillus spp., Lactobacillus reuteri and its expression in Escherichia coli. Lett Appl Microbiol 17(2):61-64. https://doi. org/10.1111/j.1472-765x.1993.tb00371.x

Caspeta L, Flores N, Pérez NO, Bolívar F, Ramírez OT (2009) The effect of heating rate on Escherichia coli metabolism, physiological stress, transcriptional response, and production of temperature-induced recombinant protein: a scale-down study. Biotechnol Bioeng 102(2):468-482. https://doi. org/10.1002/bit.22084

Cho H-J, Choi K-P, Yamashita M, Morikawa H, Murooka Y (1995) Introduction and expression of the Streptomyces cholesterol oxidase gene (ChOA), a potent insecticidal protein active against boll weevil larvae, into tobacco cells. Appl Microbiol Biotechnol 44(1-2):133-138

Collins T, Azevedo-Silva J, da Costa A, Branca F, Machado R, Casal M (2013) Batch production of a silk-elastin-like protein in E. coli BL21(DE3): key parameters for optimisation. Microbial Cell Fact 12(1):21. https://doi. org/10.1186/1475-2859-12-21

Corbin DR, Greenplate JT, Wong EY, Purcell JP (1994) Cloning of an insecticidal cholesterol oxidase gene and its expression in bacteria and in plant protoplasts. Appl Environ Microbiol 60(12):4239-4244

Doukyu N (2009) Characteristics and biotechnological applications of microbial cholesterol oxidases. Appl Microbiol Biotechnol 83(5):825-837. https ://doi.org/10.1007/s00253-009-2059-8

Doukyu N, Shibata K, Ogino H, Sagermann M (2008) Purification and characterization of Chromobacterium sp. DS-1 cholesterol oxidase with thermal, organic solvent, and detergent tolerance. Appl Microbiol Biotechnol 80(1):59

Doukyu N, Shibata K, Ogino H, Sagermann M (2009) Cloning, sequence analysis, and expression of a gene encoding Chromobacterium sp. DS-1 cholesterol oxidase. Appl Microbiol Biotechnol 82(3):479-490. https://doi. org/10.1007/s00253-008-1775-9

Fujishiro K, Ota T, Hasegawa M, Yamaguchi K, Mizukami T, Uwajima T (1990) Isolation and identification of the gene of cholesterol oxidase from Brevibacterium sterolicum ATCC 21387, a widely used enzyme in clinical analysis. Biochem Biophys Res Commun 172(2):721-727. https://doi. org/10.1016/0006-291X(90)90734-5

Gadda G, Wels G, Pollegioni L, Zucchelli S, Ambrosius D, Pilone MS, Ghisla S (1997) Characterization of cholesterol oxidase from Streptomyces hygroscopicus and Brevibacterium sterolicum. Eur J Biochem 250(2):369-376

Horii M, Ishizaki T, Paik SY, Manome T, Murooka Y (1990) An operon containing the genes for cholesterol oxidase and a cytochrome P-450-like protein from a Streptomyces sp. J Bacteriol 172(7):3644-3653. https://doi. org/10.1128/jb.172.7.3644-3653.1990

Ishizaki T, Hirayama N, Shinkawa H, Nimi O, Murooka Y (1989) Nucleotide sequence of the gene for cholesterol oxidase from a Streptomyces sp. J Bacteriol 171(1):596-601

Jevševar S, Gaberc-Porekar V, Fonda I, Podobnik B, Grdadolnik J, Menart V (2005) Production of nonclassical inclusion bodies from which correctly folded protein can be extracted. Biotechnol Prog 21(2):632-639. https:// doi.org/10.1021/bp\%5b0497839

Jin DJ, Cagliero C, Zhou YN (2012) Growth rate regulation in Escherichia coli. FEMS Microbiol Rev 36(2):269-287. https://doi.org/10.111 1/j.1574-6976.2011.00279.x

Kamei T, Takiguchi Y, Suzuki H, Matsuzaki M, Nakamura S (1978) Purification of $3 \beta$-hydroxysteroid oxidase of Streptomyces violascens origin by affinity chromatography on cholesterol. Chem Pharm Bull 26(9):2799-2804

Khow O, Suntrarachun S (2012) Strategies for production of active eukaryotic proteins in bacterial expression system. Asian Pac J Trop Biomed 2(2):159. https://doi.org/10.1016/S2221-1691(11)60213-X

Kiefhaber T, Rudolph R, Kohler H-H, Buchner J (1991) Protein aggregation in vitro and in vivo: a quantitative model of the kinetic competition between folding and aggregation. Nat Biotechnol 9(9):825

Kumari L, Kanwar SS (2012) Cholesterol oxidase and its applications. Adv Microbiol 2(2):49-65

Lartillot S, Kedziora P (1990) Production, purification and some properties of cholesterol oxidase from a streptomyces Sp. Prep Biochem 20(1):51-62

Li B, Wang W, Wang FQ, Wei DZ (2010) Cholesterol oxidase ChoL is a critical enzyme that catalyzes the conversion of diosgenin to 4-ene-3-keto 
steroids in Streptomyces virginiae IBL-14. Appl Microbiol Biotechnol 85(6):1831-1838. https://doi.org/10.1007/s00253-009-2188-0

Liu WH, Meng MH, Chen KS (1988) Purification and some properties of cholesterol oxidases produced by an inducible and a constitutive mutant of Arthrobacter simplex. Agric Biol Chem 52(2):413-418. https://doi. org/10.1271/bbb1961.52.413

Löw C, Jegerschöld C, Kovermann M, Moberg P, Nordlund P (2012) Optimisation of over-expression in E. coli and biophysical characterisation of human membrane protein synaptogyrin 1. PLoS ONE 7(6):e38244. https ://doi.org/10.1371/journal.pone.0038244

Lv C, Tang Y, Wang L, Ji W, Chen Y, Yang S, Wang W (2002) Bioconversion of yolk cholesterol by extracellular cholesterol oxidase from Brevibacterium sp. Food Chem 77(4):457-463. https://doi.org/10.1016/S0308-8146(01)00381 $-8$

Ma P, Varela F, Magoch M, Silva AR, Rosario AL, Brito J, Oliveira TF, Nogly P, Pessanha M, Stelter M, Kletzin A, Henderson PJ, Archer M (2013) An efficient strategy for small-scale screening and production of archaeal membrane transport proteins in Escherichia coli. PLoS ONE 8(10):e76913. https://doi. org/10.1371/journal.pone.0076913

MacLachlan J, Wotherspoon A, Ansell R, Brooks C (2000) Cholesterol oxidase: sources, physical properties and analytical applications. J Steroid Biochem Mol Biol 72(5):169-195

Mizukami T, Komatsu Y, Hosoi N, Itoh S, Oka T (1986) Production of active human interferon- $\beta$ in $E$. coli I. Preferential production by lower culture temperature. Biotechnology letters 8(9):605-610

Molnár I, Choi KP, Hayashi N, Murooka Y (1991) Secretory overproduction of Streptomyces cholesterol oxidase by Streptomyces lividans with a multi-copy shuttle vector. J Ferment Bioeng 72(5):368-372. https://doi. org/10.1016/0922-338X(91)90089-Y

Moradpour Z, Ghasemian A (2016) Protein engineering of microbial cholesterol oxidases: a molecular approach toward development of new enzymes with new properties. Appl Microbiol Biotechnol 100(10):43234336. https://doi.org/10.1007/s00253-016-7497-5

Murooka Y, Ishizaki T, Nimi O, Maekawa N (1986) Cloning and expression of a Streptomyces cholesterol oxidase gene in Streptomyces lividans with plasmid plJ702. Appl Environ Microbiol 52(6):1382-1385

Nishiya Y, Harada N, Teshima SI, Yamashita M, Fujii I, Hirayama N, Murooka Y (1997) Improvement of thermal stability of Streptomyces cholesterol oxidase by random mutagenesis and a structural interpretation. Protein Eng 10(3):231-235

Nomura N, Choi KP, Yamashita M, Yamamoto H, Murooka Y (1995) Genetic modification of the Streptomyces cholesterol oxidase gene for expression in Escherichia coli and development of promoter-probe vectors for use in enteric bacteria. J Ferment Bioeng 79(5):410-416. https://doi. org/10.1016/0922-338X(95)91253-2

Ohta T, Fujishiro K, Yamaguchi K, Uwajima T, Aisaka K, Hasegawa M (1992) Hyperexpression and analysis of choB encoding cholesterol oxidase of Bvevibactevium sterolicum in Escherichia coli and Streptomyces lividans. Biosci Biotechnol Biochem 56(11):1786-1791. https://doi.org/10.1271/ bbb. 56.1786

Pollegioni L, Piubelli L, Molla G (2009) Cholesterol oxidase: biotechnological applications. FEBS J 276(23):6857-6870. https://doi.org/10.111 1/j.1742-4658.2009.07379.x

Purcell JP, Greenplate JT, Jennings MC, Ryerse JS, Pershing JC, Sims SR, Prinsen MJ, Corbin DR, Tran M, Sammons RD, Stonard RJ (1993) Cholesterol oxidase: a potent insecticidal protein active against boll weevil larvae. Biochem Biophys Res Commun 196(3):1406-1413. https://doi.org/10.1006/ bbrc.1993.2409
Rosano GL, Ceccarelli EA (2014) Recombinant protein expression in Escherichia coli: advances and challenges. Front Microbiol 5:172. https://doi. org/10.3389/fmicb.2014.00172

Sahdev S, Khattar SK, Saini KS (2008) Production of active eukaryotic proteins through bacterial expression systems: a review of the existing biotechnology strategies. Mol Cell Biochem 307(1-2):249-264. https://doi. org/10.1007/s11010-007-9603-6

Saïda F (2007) Overview on the expression of toxic gene products in Escherichia coli. Curr Protoc Protein Sci 50(1):5.19. 1-5.19. 13. https://doi. org/10.1002/0471140864.ps0519s50

Serajzadeh S, Alemzadeh I (2010) Low-cholesterol milk production using cholesterol oxidase from Nocardia erythropolis. Aust I Dairy Technol 65(1):10-14

Sivashanmugam A, Murray V, Cui C, Zhang Y, Wang J, Li Q (2009) Practical protocols for production of very high yields of recombinant proteins using Escherichia coli. Protein Sci 18(5):936-948

Smith AG, Brooks CJ (1976) Cholesterol oxidases: properties and applications. J Steroid Biochem 7(9):705-713

Smith M, Sullivan C, Goodman N (1991) Reactivity of milk cholesterol with bacterial cholesterol oxidases. J Agric Food Chem 39(12):2158-2162

Solaiman DKY, Somkuti GA (1991) Expression of streptomycete cholesterol oxidase in Escherichia coli. J Ind Microbiol 8(4):253-258. https://doi. org/10.1007/BF01576063

Solaiman DKY, Somkuti GA (1995) Expression of Streptomyces melC and choA genes by a cloned Streptococcus thermophilus promoter STP2201. J Ind Microbiol 15(1):39-44. https://doi.org/10.1007/BF01570011

Solaiman DKY, Somkuti GA, Steinberg DH (1992) Construction and characterization of shuttle plasmids for lactic acid bacteria and Escherichia coli. Plasmid 28(1):25-36. https://doi.org/10.1016/0147-619X(92)90033-7

Somkuti GA, Solaiman DKY (1997) ST(P2201), a chromosomal promoter sequence of Streptococcus thermophilus. Curr Microbiol 35(3):180-185. https://doi.org/10.1007/s002849900235

Somkuti G, Solaiman D, Johnson T, Steinberg D (1991) Transfer and expression of a Streptomyces cholesterol oxidase gene in Streptococcus thermophilus. Biotechnol Appl Biochem 13(2):238-245. https://doi, org/10.1111/j.1470-8744.1991.tb00153.x

Somkuti GA, Solaiman DKY, Steinberg DH (1995) Native promoter-plasmid vector system for heterologous cholesterol oxidase synthesis in streptococcus thermophilus. Plasmid 33(1):7-14. https://doi.org/10.1006/plas.1995.1002

Sørensen HP, Mortensen KK (2005) Soluble expression of recombinant proteins in the cytoplasm of Escherichia coli. Microb Cell Fact 4(1):1. https://doi. org/10.1186/1475-2859-4-1

Stano NM, Patel SS (2004) T7 lysozyme represses T7 RNA polymerase transcription by destabilizing the open complex during initiation. J Biol Chem 279(16):16136-16143. https://doi.org/10.1074/jbc.M400139200

Tabatabaei Yazdi M, Malekzadeh F, Zarrini G, Faramarzi MA, Kamranpour N, Khaleghparast S (2001) Production of cholesterol oxidase by a newly isolated Rhodococcus sp. World J Microbiol Biotechnol 17(7):731-737. https://doi.org/10.1023/A:1012993532686

Tomioka H, Kagawa M, Nakamura S (1976) Some enzymatic properties of $3 \beta$-hydroxysteroid oxidase produced by Streptomyces violascens. J Biochem 79(5):903-915

Vrielink A, Ghisla S (2009) Cholesterol oxidase: biochemistry and structural features. FEBS J 276(23):6826-6843. https://doi.org/10.111 1/j.1742-4658.2009.07377.x

Yehia HM, Hassanein WA, Ibraheim SM (2015) Purification and characterisation of the extracellular cholesterol oxidase enzyme from Enterococcus hirae. BMC Microbiol 15(1):178. https://doi.org/10.1186/s12866-015-0517-2 